\title{
EVALUATION OF IMPACT OF COMBUSTION ENGINE CONTROLLER ADAPTATION PROCESS ON LEVEL OF EXHAUST GAS EMISSIONS IN GASOLINE AND COMPRESSED NATURAL GAS SUPPLY PROCESS
}

\author{
Marcin Dziewiatkowski, Dariusz Szpica, Andrzej Borawski \\ Bialystok University of Technology, Poland \\ marcin.dziewiatkowski@ac.com.pl,d.szpica@pb.edu.pl, \\ a.borawski@pb.edu.pl
}

\begin{abstract}
Nowadays in many countries, where the conversion of internal combustion engines into alternative gas fuel is economically justified, the installation of CNG fuel systems dominates. According to official data, about 20 million vehicles with engines running on this fuel travel on the roads. Given the significant increase in the number of conversions carried out, special attention should be paid to the level of exhaust emissions of these vehicles. As many researchers show in their publications, combustion of this type of fuel emits less toxic compounds to the atmosphere than conventional fuels. Therefore, ecological aspects also speak for its use, which nowadays, mainly due to significant air pollution, are extremely important. In the case of conversion of vehicles with gasoline engines sequentially controlled by the engine controller, it is possible to adjust the adaptation of the parameters of this controller in various driving cycles, which affects the changes in vehicle emissions from the initial settings of this system. The article describes a number of bench tests that confirm the above statement. Extensive measuring equipment was used, which included, among others, the chassis dynamometer and exhaust gas analyzer. The results of the tests clearly showed that with the passage of using time of the vehicle (increasing mileage) one of the parameters in the control system changes significantly, which also changes the level of exhaust emissions. Unfortunately, this is an unwanted change. It has been suggested to counteract this phenomenon by emulating the lambda probe signal. The proposed solution has been implemented and tested. A series of exhaust emission tests of an engine equipped with a modified power supply system showed the correctness of the adopted solution.
\end{abstract}

Keywords: mechanical engineering, alternative fuel, chassis dynamometer, CNG.

\section{Introduction}

The fuel combustion process is inherently accompanied by $\mathrm{CO}_{2}$ emissions $[1 ; 2]$. Therefore, each time when approving a vehicle, it must meet the emission requirements depending on current legal regulations [3]. Downsizing [4] was the first step to contribute to reducing $\mathrm{CO}_{2}$ emissions. Other activities include optimization of the combustion process and exhaust gas purification or the use of fuels with reduced carbon content $[5 ; 6]$. The main fuels with lower carbon content are: liquefied petroleum gas (LPG) [7;8], compressed natural gas (CNG) [9-13], as well as liquefied natural gas (LNG) [14-16]. Dual-fuel systems are also used [17-19]. The Alternative Motor Fuels Act provides special treatment in calculating the fuel consumption of alternative fuel vehicles [20].

Very often in the course of research of alternative fuel powered engines, there are fluctuations in exhaust emissions, especially in cooperation with gas controllers and new generation gasoline controllers [21-24]. The problem is important, because it determines the approval process for the alternative power system. The gas controller uses signals that control the operation of gasoline injectors, but due to differences in the structure and operation of systems and the properties of fuels, a simple proportion cannot be assumed [25]. The evaluation of power supply systems is performed on ongoing data based on signals from lambda sensors or crankshaft rotational speed sensors. In laboratory and approval homologation tests, chassis dynamometers, special testing procedures and exhaust gas analyzers are used [26].

The differences in the combustion of classic and alternative fuels in earlier legal regulations did not cause the emission standards to be exceeded, while at the moment they can be a problem. Small differences in fuel dosage resulting from the uniqueness [27] or unevenness [28] of alternative fuel dosage result in not only an increase in exhaust emissions, but also the check engine reporting by the engine control system. A solution can be the use of piezoelectric drives in gas injectors [29-32], or the solution of wear problems in cooperating pairs [33; 34].

The aim of this study is the attempts to solve the problem of increased and unstable exhaust emissions of an alternative fuel engine using a lambda sensor signal emulator. 


\section{Object and methodology of the research}

The object of the study was a Hyundai i20 car equipped with an additional CNG alternative fuel supply system. The technical data of it (which from the point of view of the research were most important) are presented in Tab. 1.

Basic technical data of the Hyundai i30

Table 1

\begin{tabular}{|l|c|c|}
\hline \multicolumn{1}{|c|}{ Parameter } & Unit & Value \\
\hline Year of the manufacture & - & 2018 \\
\hline Engine displacement & $\mathrm{L}$ & 1.248 \\
\hline Max. power / at engine speed & $\mathrm{kW} / \mathrm{rpm}$ & $86 / 6000$ \\
\hline Max. torque / at engine speed & $\mathrm{Nm} / \mathrm{rpm}$ & $122 / 4000$ \\
\hline Engine vehicles with respect to emissions & - & EURO 6 \\
\hline Fuel & - & RON 95 \\
\hline Alternative fuel & - & CNG \\
\hline Mileage & $\mathrm{km}$ & 1080 \\
\hline Gearbox & - & Manuals 5 gear \\
\hline
\end{tabular}

The alternative CNG supply system included:

- $\quad$ STAG gas controller, model QNEXT PLUS;

- Matrix gas injectors, model HD344;

- $\quad$ STAG reducer, model R14;

- Elpigas cylindrical tank.

The research was performed on a modern, technically advanced laboratory stand. It includes, among others: Horiba Vulcan chassis dynamometer (Force per Axle: 5400 N, Power per Axle: $155 \mathrm{~kW}$, Maximum Speed: $200 \mathrm{~km} \cdot \mathrm{h}^{-1}$ ), HORIBA STARS VETS measurement system - exhaust emission tester (the ability to measure CO, HC, NOx with accuracy $0.001 \mathrm{~g} \cdot \mathrm{km}^{-1}$ ), ETAS software, INCA 7.0 model, Interpid communication interface and ValuCAN3 model.

The chassis dynamometer allowed for quasidynamic testing of the vehicle in laboratory conditions. The tests used the dynamometer function called by the manufacturer driving simulation. Driving simulation (also called road simulation) is used for laboratory mapping of road conditions. All components of the vehicle's equation of motion, such as rolling resistance, air resistance, and hill resistance, are included here. Regulation and automatic loss compensation is available from $0 \mathrm{~km} / \mathrm{h}$ up to rated speed. The test in the driving simulation mode can be made motorically and generically. During tests, using the Horiba software, a set of vehicle parameters, such as curb weight, air resistance coefficient, rolling resistance coefficient, was introduced into the dynamometer controller. The dynamometer also has an encoded NEDC (New European Driving Cycle), which was also used to measure the exhaust emissions of the vehicle.

The exhaust emission tester used in the course of the tests gives the opportunity to measure gases generated by gasoline and gas fueled engines (both LPG and CNG). The final results, obtained after the end of the test, are presented in units of $\mathrm{g} \cdot \mathrm{km}^{-1}$ of individual measured exhaust gases. For the tests, the possibility of measuring the level of $\mathrm{HC}, \mathrm{CO}$ and $\mathrm{NO}_{\mathrm{x}}$ gas emissions was used.

In addition, thanks to the ETAS software, it was possible to read the internal parameters of the gasoline controller and analyze these parameters based on their course in real time, as well as their recording and subsequent analysis as recorded data. In the considered case, the program function described by the manufacturer as "Measurement data acquisition, acquisition and online display of measurement values, calibration parameters (scalars, characteristic curves/diagrams), numerous trigger options, online calculation and representation of derived signals, ECU (Engine Control Unit) storage dump in hex and physical representation" was used. It was also necessary to communicate with the vehicle via the USB protocol of the PC. This was accomplished through the OBD (On-Board Diagnostics) diagnostic socket and Interpid communication interface, ValuCAN3 model. In the studied case CAN-XCP communication was used. 
The measuring process was carried out in accordance with the Euro 6 regulation [35]. The tests were carried out at an ambient temperature between $20-23^{\circ} \mathrm{C}$ (requirement is $25^{\circ} \mathrm{C} \pm 5{ }^{\circ} \mathrm{C}$ ). Each emission measurement was carried out after conditioning the vehicle for at least 6 hours. During each exhaust emission measurement, a PC with INCA 7.0 software was connected to the petrol controller using the Valuecan module to record internal parameters. The key parameter that was observed as the one affecting the fuel dose correction was DLAHI (Development Lambda sensor High Integrator). This is the fuel dose correction factor due to the diagnostic signal of the lambda sensor. It aims at adjusting the fuel dose in a situation, where the signal path of the second lambda sensor indicates that the effective catalyst operation is starting too slowly after exiting the transient states of engine operation. Its changes directly affect the change of the fuel injection time. The principle of the gas controller is based on the measurement of gasoline injection time, then multiplying this time by a number of coefficients contained in the internal gas controller algorithm, and finally sending the calculated injection time to the gas injector [36]. In the process of initial calibration of the gas controller, the internal algorithm of the controller calculates a number of factors depending, among others, on the gas temperature and pressure, as well as the vacuum in the engine intake manifold [37]. In order to verify the operation of the change in the fuel dose correction factor, the first measurement was taken of the exhaust gas emission while supplying gasoline and with observation of engine performance, such as: STFT (Short Term Fuel Trim), LTFT (Long Term Fuel Trim) and DLAHI. Then the same measurements were made, when the engine was supplied with CNG fuel. In subsequent measurements, lambda sensor signal emulation was used to limit the adaptation of the petrol controller parameters. In the obtained measurement data, it was observed how the correction factor changes and how it affects the change in the fuel dose and the level of exhaust emissions.

\section{Results and discussions}

The data from the exhaust gas analyser was a direct test result. As already mentioned, the tests were performed in three stages: with gasoline (Tab. 2), with nominal CNG (Tab. 3) and with CNG and using a lambda sensor emulator (Tab. 4).

Table 2

Gasoline supply test results

\begin{tabular}{|c|c|c|c|c|c|c|c|c|c|}
\hline \multirow{2}{*}{ No. } & \multicolumn{2}{|c|}{$\begin{array}{c}\text { STFT, } \\
(\mathrm{max} / \mathrm{min}), \%\end{array}$} & \multicolumn{2}{|c|}{$\begin{array}{c}\text { LTFT, } \\
(\max / \min ), \%\end{array}$} & \multirow{2}{*}{$\begin{array}{c}\text { DLAHI } \\
\text { before test }\end{array}$} & \multirow{2}{*}{$\begin{array}{c}\text { DLAHI } \\
\text { after test }\end{array}$} & \multirow{2}{*}{$\begin{array}{c}\mathrm{CO}, \\
\mathrm{g} \cdot \mathbf{k m}^{-1}\end{array}$} & \multirow{2}{*}{$\begin{array}{l}\mathrm{HC}, \\
\mathrm{g} \cdot \mathrm{km}^{-1}\end{array}$} & \multirow{2}{*}{$\begin{array}{l}\text { NOx, } \\
\mathrm{g} \cdot \mathbf{k m}^{-1}\end{array}$} \\
\hline & $\begin{array}{c}\text { before } \\
\text { test }\end{array}$ & $\begin{array}{c}\text { after } \\
\text { test }\end{array}$ & $\begin{array}{c}\text { before } \\
\text { test }\end{array}$ & $\begin{array}{c}\text { after } \\
\text { test }\end{array}$ & & & & & \\
\hline 1 & $5 /-6$ & $4 /-5$ & $3 / 3$ & $4 / 4$ & 0.000121 & 0.000136 & 0.533 & 0.035 & 0.022 \\
\hline 2 & $5 /-6$ & $4 /-5$ & $3 / 3$ & $4 / 3$ & 0.000136 & 0.000136 & 0.488 & 0.050 & 0.022 \\
\hline 3 & $5 /-6$ & $7 /-5$ & $3 / 3$ & $4 / 4$ & 0.000136 & 0.000140 & 0.511 & 0.045 & 0.022 \\
\hline 4 & $5 /-6$ & $4 /-5$ & $3 / 3$ & $4 / 4$ & 0.000140 & 0.000142 & 0.608 & 0.070 & 0.011 \\
\hline 5 & $5 /-6$ & $4 /-5$ & $2 / 2$ & $4 / 4$ & 0.000142 & 0.000136 & 0.522 & 0.033 & 0.040 \\
\hline 6 & $4 /-6$ & $4 /-5$ & $4 / 4$ & $4 / 4$ & 0.000136 & 0.000136 & 0.530 & 0.035 & 0.022 \\
\hline 7 & $4 /-6$ & $3 /-5$ & $3 / 4$ & $3 / 4$ & 0.00 & 0.00 & 0.605 & 0.060 & 0.018 \\
\hline 8 & $5 /-6$ & $4 /-5$ & $3 / 3$ & $3 / 3$ & 0.000140 & 0.000121 & 0.531 & 0.035 & 0.022 \\
\hline 9 & $5 /-6$ & $6 /-5$ & $3 / 2$ & $4 / 3$ & 0.000121 & 0.000136 & 0.498 & 0.035 & 0.022 \\
\hline 10 & $3 /-5$ & $5 /-5$ & $3 / 3$ & $3 / 3$ & 0.000136 & 0.000136 & 0.602 & 0.055 & 0.013 \\
\hline
\end{tabular}

The first stage of measurements, made with conventional gasoline supply, can be treated as a reference, as it illustrates not only the stability of exhaust emissions in the tested vehicle, but also its level. Analysing the results and calculating the standard deviation was made of each case according to formula:

$$
\mathrm{SD}=\sqrt{\frac{\sum_{i=1}^{n}(X-Y)^{2}}{N-1}}
$$

where $X$ - single result value;

$Y$ - average value; 
$N$ - number of measurments;

It can be stated that in this case:

- average $\mathrm{CO}$ emission is $0.542 \pm 0.0453 \mathrm{~g} \cdot \mathrm{km}^{-1}$, the highest measured $\mathrm{CO}$ emission is $0.608 \mathrm{~g} \cdot \mathrm{km}^{-1}$ (for the Euro 6 limit is $1.000 \mathrm{~g} \cdot \mathrm{km}^{-1}$, the test result is therefore $60.8 \%$ of the limit value);

- average $\mathrm{HC}$ emission is $0.045 \pm 0.013 \mathrm{~g} \cdot \mathrm{km}^{-1}$, the highest measured $\mathrm{HC}$ emission is $0.070 \mathrm{~g} \cdot \mathrm{km}^{-1}$ (for Euro 6 the limit is $0.1 \mathrm{~g} \cdot \mathrm{km}^{-1}$, thus the test result is $70 \%$ of the limit value);

- the average $\mathrm{NO}_{\mathrm{x}}$ emission is $0.021 \pm 0.008 \mathrm{~g} \cdot \mathrm{km}^{-1}$, the highest measured $\mathrm{NO}_{\mathrm{x}}$ emission is $0.040 \mathrm{~g} \cdot \mathrm{km}^{-1}$ (for Euro 6 the limit is $0.060 \mathrm{~g} \cdot \mathrm{km}^{-1}$, so the test result is $66.6 \%$ of the limit value).

Table 3

CNG supply test results

\begin{tabular}{|c|c|c|c|c|c|c|c|c|c|}
\hline \multirow{2}{*}{ No. } & \multicolumn{2}{|c|}{$\begin{array}{c}\text { STFT, } \\
\text { (max/min), \% }\end{array}$} & \multicolumn{2}{|c|}{$\begin{array}{c}\text { LTFT, } \\
(\max / \mathbf{m i n}), \%\end{array}$} & \multirow{2}{*}{$\begin{array}{c}\text { DLAHI } \\
\text { before test }\end{array}$} & \multirow{2}{*}{$\begin{array}{c}\text { DLAHI } \\
\text { after test }\end{array}$} & \multirow{2}{*}{$\begin{array}{l}\mathrm{CO}, \\
\mathrm{g} \cdot \mathbf{k m}^{-1}\end{array}$} & \multirow{2}{*}{$\begin{array}{l}\text { NMHC, } \\
\mathbf{g} \cdot \mathbf{k m}^{-1}\end{array}$} & \multirow{2}{*}{$\begin{array}{l}\text { NOx, } \\
\mathbf{g} \cdot \mathbf{k m}^{-1}\end{array}$} \\
\hline & $\begin{array}{c}\text { before } \\
\text { test }\end{array}$ & $\begin{array}{c}\text { after } \\
\text { test }\end{array}$ & $\begin{array}{c}\text { before } \\
\text { test }\end{array}$ & $\begin{array}{c}\text { after } \\
\text { test }\end{array}$ & & & & & \\
\hline 1 & $6 /-5$ & $5 /-5$ & $4 / 3$ & $5 / 4$ & 0.00 & 136 & 0.655 & 0.057 & .011 \\
\hline 2 & $7 /-5$ & $5 /-5$ & $5 / 3$ & $5 / 3$ & 136 & 0.000160 & 0.702 & 0.065 & 0.017 \\
\hline 3 & $5 /-6$ & $7 /-5$ & $5 / 3$ & $4 / 5$ & 0.00 & 0.00 & 0.802 & 0.080 & 0.044 \\
\hline 4 & $8 /-6$ & $6 /-5$ & $3 / 3$ & $4 / 4$ & 0.000240 & 0.000320 & 0.850 & 0.080 & 0.011 \\
\hline 5 & $6 /-8$ & $5 /-5$ & $2 / 3$ & $4 / 4$ & 0.000320 & 0.000360 & 0.870 & 0.095 & 0.008 \\
\hline 6 & $5 /-5$ & $4 /-5$ & $4 / 5$ & $4 / 3$ & 0.000360 & 0.000380 & 0.350 & 0.040 & 0.101 \\
\hline 7 & $3 /-4$ & $6 /-5$ & $3 / 4$ & $3 / 4$ & 0.000380 & 0.000420 & 0.480 & 0.060 & 0.033 \\
\hline 8 & $5 /-6$ & $6 /-5$ & $3 / 3$ & $3 / 5$ & 0.000420 & 0.000560 & 0.780 & 0.070 & 0.010 \\
\hline 9 & $3 /-3$ & $4 /-5$ & $3 / 2$ & $4 / 4$ & 560 & 0.000780 & 0.950 & 0.088 & 0.008 \\
\hline 10 & $2 /-5$ & $5 /-5$ & $3 / 4$ & $3 / 4$ & 0.000780 & 0.001250 & 0.980 & 0.120 & 0.005 \\
\hline
\end{tabular}

CNG supply with lambda sensors emulator test results

Table 4

\begin{tabular}{|c|c|c|c|c|c|c|c|c|c|}
\hline \multirow{2}{*}{ No. } & \multicolumn{2}{|c|}{$\begin{array}{c}\text { STFT, } \\
\text { (max/min), \% }\end{array}$} & \multicolumn{2}{|c|}{$\begin{array}{c}\text { LTFT, } \\
(\max / \min ), \%\end{array}$} & \multirow{2}{*}{$\begin{array}{c}\text { DLAHI } \\
\text { before test }\end{array}$} & \multirow{2}{*}{$\begin{array}{c}\text { DLAHI } \\
\text { after test }\end{array}$} & \multirow{2}{*}{$\begin{array}{l}\mathrm{CO}, \\
\mathbf{g} \cdot \mathbf{k m}^{-1}\end{array}$} & \multirow{2}{*}{$\begin{array}{l}\text { NMHC, } \\
\mathbf{g} \cdot \mathbf{k m}^{-1}\end{array}$} & \multirow{2}{*}{$\begin{array}{l}\text { NOx, } \\
\mathbf{g} \cdot \mathbf{k m}^{-1}\end{array}$} \\
\hline & $\begin{array}{c}\text { before } \\
\text { test }\end{array}$ & $\begin{array}{c}\text { after } \\
\text { test }\end{array}$ & $\begin{array}{c}\text { before } \\
\text { test }\end{array}$ & $\begin{array}{c}\text { after } \\
\text { test }\end{array}$ & & & & & \\
\hline 1 & $5 /-6$ & $4 /-5$ & $2 / 4$ & $4 / 4$ & & & 3 & & 2 \\
\hline 2 & $5 /-5$ & $4 /-5$ & $3 / 3$ & $4 / 3$ & & & 0.488 & & \\
\hline 3 & $5 /-6$ & $4 /-5$ & 31 & $3 / 4$ & & & & & \\
\hline 4 & $3 /-4$ & $4 /-5$ & $3 / 3$ & $4 / 3$ & & & & & \\
\hline 5 & $4 /-3$ & $4 /-5$ & $4 / 2$ & $4 / 4$ & & & & & \\
\hline 6 & $3 /-4$ & $4 /-5$ & $4 / 3$ & $4 / 3$ & & & 30 & & 022 \\
\hline 7 & $2 /-5$ & $3 /-4$ & $4 / 4$ & $2 / 4$ & & & & & 018 \\
\hline 8 & $5 /-5$ & $4 /-5$ & $3 / 3$ & $3 / 3$ & & & 0.531 & & 022 \\
\hline 9 & $4 /-5$ & $4 /-5$ & $3 / 3$ & $4 / 4$ & 0.0 & 0.0 & 0.498 & 0.035 & 0.022 \\
\hline 10 & $3 /-4$ & $5 /-5$ & $3 / 3$ & $3 / 4$ & 36 & 136 & 0.602 & 0.055 & 0.01 \\
\hline
\end{tabular}

During the measurements, the oscillation of the DLAHI coefficient was also observed at the level of $121 \mathrm{E}-6$ to $140 \mathrm{E}-6$. This, however, did not have a significant impact, because this oscillation only affects the maximum differentiation of exhaust emissions at the level of:

- $\mathrm{CO}=0.120 \mathrm{~g} \cdot \mathrm{km}^{-1}$;

- $\mathrm{HC}=0.035 \mathrm{~g} \cdot \mathrm{km}^{-1}$

- $\mathrm{NO}_{\mathrm{x}}=0.011 \mathrm{~g} \cdot \mathrm{km}^{-1}$.

In the next stage, the research object was powered by alternative fuel (CNG). From the obtained results it can be concluded that: 
- the average $\mathrm{CO}$ emission is $0.714 \pm 0.201 \mathrm{~g} \cdot \mathrm{km}^{-1}$, the highest measured $\mathrm{CO}$ emission is $0.980 \mathrm{~g} \cdot \mathrm{km}^{-1}$ (the test result is $98 \%$ of the limit value);

- the average $\mathrm{HC}$ emission is $0.075 \pm 0.022 \mathrm{~g} \cdot \mathrm{km}^{-1}$, the highest measured $\mathrm{HC}$ emission is $0.120 \mathrm{~g} \cdot \mathrm{km}^{-1}$ (the test result is $120 \%$ of the limit value);

- the average $\mathrm{NO}_{\mathrm{x}}$ emission is $0.026 \pm 0.029 \mathrm{~g} \cdot \mathrm{km}^{-1}$, the highest measured $\mathrm{NO}_{\mathrm{x}}$ emission is $0.101 \mathrm{~g} \cdot \mathrm{km}^{-1}$ (in the case of Euro 6 the limit is $0.060 \mathrm{~g} \cdot \mathrm{km}^{-1}$, so the test result is $168 \%$ of the limit value).

It should also be noted that the emission level indicators were much more unstable compared to conventional fuel supply. The DLAHI factor increases steadily from 121E-6 up to 1250E-6, while the range of exhaust emission results is respectively:

- for $\mathrm{CO}=0.630 \mathrm{~g} \cdot \mathrm{km}^{-1}$;

- for $\mathrm{HC}=0.063 \mathrm{~g} \cdot \mathrm{km}^{-1}$;

- for $\mathrm{NO}_{\mathrm{x}}=0.039 \mathrm{~g} \cdot \mathrm{km}^{-1}$.

The direct impact of the result of the adaptation of the DLAHI factor on the increase of individual gas emissions and the destabilization of the final results is clearly visible. The phenomenon observed during these measurements is associated with a change in the nature of the lambda sensor signal along with a change from conventional fuel (to which the test object was factory-fitted) to alternative. In the case of stoichiometric combustion of gasoline, the AFR (Air-Fuel Ratio) ratio is 14.7 and the gasoline controller is programmed to this proportion of the fuel-air mixture. In the case of CNG supply, the AFR increases to 17.2. This is one of the factors that affects the adaptation of controllers in transient states. The second, more significant, is the physicochemical difference of fuels, and thus - other substrates of the combustion process in the engine cylinder. The exhaust gases contain a different oxygen level despite the correct preparation of the mixture ratio in the stoichiometric cycle. In many modern internal combustion engines, the factory CPU controls the efficiency of the catalyst by precisely controlling the voltage response of the lambda sensors diagnostic signal. The fuel dose correction factor depends on the oxygen content in the exhaust gas (measurement is carried out behind the catalyst) and the injection time is adjusted on its basis. The level of this adaptation (while working on $\mathrm{CNG}$ ) is several times higher than in the case of engine operation on gasoline fuel, and in the studied case it increased from 121E-6 units to $1250 \mathrm{E}-6$ (over 10 times). The change introduced on this basis causes unnecessary enrichment or reduction of the fuel dose, which is delayed by the factory controller based on the analysis of the signal of the first lambda sensor. Additionally, it can be observed that changes in the fuel dose correction parameter from the second lambda sensor are not visible by reading the dose integrators available via global OBD, i.e. STFT and LTFT. In all tests, the values of these corrections remain in oscillation at a similar level, both when running on gasoline, as well as when running on CNG. As a result of the development of the gas controller, in order to avoid this phenomenon, the company AC LLC (manufacturer of the STAG brand) in its controller applied an additional solution based on appropriate modification (emulation) of the lambda sensor signal. The results of this solution can be observed by analysing the results of the third stage of the research. It is clear that already in the first measurement the emission level is reduced. $\mathrm{CO}$ emissions fall about $24 \%$ from $0.714 \pm 0.201 \mathrm{~g} \cdot \mathrm{km}^{-1}$ to $0.542 \pm 0.045 \mathrm{~g} \cdot \mathrm{km}^{-1}$, while $\mathrm{HC}$ levels are lower of around $39 \%$ (from $0.075 \pm 0.022 \mathrm{~g} \cdot \mathrm{km}^{-1}$ to $\left.0.046 \pm 0.015 \mathrm{~g} \cdot \mathrm{km}^{-1}\right)$. NOx drop is lower $(-20 \%)$ from $0.026 \pm 0.029 \mathrm{~g} \cdot \mathrm{km}^{-1}$ to $0.021 \pm 0.008$. In subsequent measurements, the DLAHI correction level stabilizes and assumes the same value as for the measurements carried out with gasoline. Similar trends were observed in the emission levels of the measured compounds.

\section{Conclusions}

1. During the tests, the phenomenon of unstable emissions of the vehicle was observed. Based on the fuel dose adjustment data received from the vehicle manufacturer, it was concluded that the petrol controller changes the fuel dosage adaptation while driving. This is done on the basis of an analysis of the signal path of the lambda sensor located behind the exhaust gas catalyst.

2. In each subsequent emission measurement cycle, the fuel dose correction parameter increased its value, influencing the extension of the injection time in certain areas of the fuel map, resulting in enrichment of the mixture. This process directly affected the signal path of the lambda (control) 
sensor located in front of the catalyst. This triggered the integrator of the first lambda sensor to lean the mixture.

3. In transient states, temporary changes in exhaust emissions affect the final emission result, increasing the content of nitrogen oxides and hydrocarbon compounds by up to $100 \%$ compared to the initial controller settings. In order to avoid this phenomenon, the lambda sensor signal was emulated.

4. After selecting the appropriate signal emulation values, the phenomenon of the negative adaptation of the gasoline controller has been eliminated. Given the above, it can be concluded that the operation is effective and eliminates problems associated with the adaptation of the gasoline controller.

\section{Funding}

This publication was financed through the program of the Ministry of Science and Higher Education of Poland named "Regional Initiative of Excellence" in 2019-2022 project number 011/RID/2018/19.

\section{Acknowledgments}

This research was co-founded through the subsidy of the Ministry of Science and Higher Education for the discipline of Mechanical Engineering at the Faculty of Mechanical Engineering, Bialystok University of Technology.

\section{References}

[1] Bleischwitz R., Bader N. Policies for the transportation toward a hydrogen economy: The EU case Energy Policy, vol. 38, 2010, pp. 5388-5398.

[2] Litschke A., Knitschky G., Future development in road freight transport regarding more environmentally friendly vehicle technology, Procedia - Social and Behavioral Sciences, vol. 48, 2012, pp. 1557-1567.

[3] Reducing CO2 emissions from passenger cars. [online] [02.02.2020]. Available at: https://ec.europa.eu/clima/policies/transport/vehicles/cars_en.

[4] Leduc L., Dubarm B., Ranini A., Monnier G. Downsizing of gasoline engine: an efficient way to reduce CO2 emissions. Oil \& Gas Science and Technology - Rev. IFP, vol. 58(1), 2003, pp. 115127.

[5] Hunicz J., Kordos P., An experimental study of fuel injection strategies in CAI gasoline engine. Experimental Thermal and Fluid Science, vol. 35, 2011,pp. 243-252.

[6] Kenihan S., Reducing the emissions from your council fleet. Cities for Climate Protection Australia: An ICLEI program in collaboration with the AGO, 1999.

[7] Raslavicius L., Kersys A., Mockus S. Kersiene N., Starevicius M. Liquefied petroleum gas (LPG) as a medium-term option in the transition to sustainable fuels and transport. Renewable \& Sustainable Energy Reviews, vol. 32, 2014, pp. 513-525.

[8] Wendeker M., Jaklinski P., Czarnigowski J., Boulet P., Breaban F. Operational parameters of LPG fuelled SI engine - comparison of simultaneous and sequential port injection. SAE Technical Paper, 2007-01-2051, 2007.

[9] Khan M.I., Yasmeen T., Khan M.I., Farooq M., Wakeel M. Research progress in the development of natural gas as fuel for road vehicles: A bibliographic review (1991-2016). Renewable and Sustainable Energy Reviews, vol. 66, 2016, pp. 702-741.

[10] Frick M., Axhausen K.W., Carle G., Wokaun A. Optimization of the distribution of compressed natural gas (CNG) refueling stations: Swiss case studies. Transportation Research Part D: Transport and Environment, vol. 12, 2007, pp. 10-22.

[11] Hekkert M.P., Hendriks F.H.J.F., Faaij A.P.C., Neelis M.L. Natural gas as an alternative to crude oil in automotive fuel chains well-to-wheel analysis and transition strategy development. Energy Policy, vol. 33, 2005, pp. 579-94.

[12] Aslam M.U., Masjuki H.H., Kalam M.A., Abdesselam H., Mahlia T.M.I., Amalina M.A. An experimental investigation of $\mathrm{CNG}$ as an alternative fuel for a retrofitted gasoline vehicle. Fuel, vol. 85,2006 , pp. 717-724. 
[13] De Carvalho Jr A.V. Natural gas and other alternative fuels for transportation purposes. Energy, vol. 10, 1985, pp. 187-215.

[14] Suurs R.A.A., Hekkert M.P., Kieboom S., Smits R.E.H.M. Understanding the formative stage of technological innovation system development: the case of natural gas as an automotive fuel. Energy Policy, vol. 38, 2010, pp. 419-31.

[15] Arteconi A, Brandoni C, Evangelista D, Polonara F. Life-cycle greenhouse gas analysis of LNG as a heavy vehicle fuel in Europe. Applied Energy, vol. 87, 2010, pp. 2005-2013.

[16] Kumar S, Kwon H-T, Choi K-H, Lim W, Cho JH, Tak KLNG. An eco-friendly cryogenic fuel for sustainable development. Applied Energy, vol. 88, 2011, pp. 4264-73.

[17] Ashok B, Ashok S.D, Kumar C.R. LPG diesel dual fuel engine - A critical review. Alexandria Engineering Journal, vol. 54, 2015, pp. 105-126.

[18] Mikulski M., Wierzbicki S., Pietak A. Numerical studies on controlling gaseous fuel combustion by managing the combustion process of diesel pilot dose in a dual-fuel engine. Chemical and Process Engineering - Inzynieria Chemiczna i Procesowa, vol. 36 (2), 2015, pp. 225-238.

[19] Pulawski G., Szpica D. The modelling of operation of the compression ignition engine powered with diesel fuel with LPG admixture. Mechanika, vol. 21(6), 2015. pp. 501-506.

[20] Liu Y., Helfand G.E. The Alternative Motor Fuels Act, alternative-fuel vehicles, and greenhouse gas emissions. Transportation Research Part A Policy and Practice, vol. 43, 2009, pp. 755-764.

[21] Mustafi N.N., Agarwal A.K. Combustion and Emission Characteristics, and Emission Control of CNG Fueled Vehicles. In: Singh A., Sharma Y., Mustafi N., Agarwal A. (eds) Alternative Fuels and Their Utilization Strategies in Internal Combustion Engines. Energy, Environment, and Sustainability. Singapore: Springer, 2020

[22] Dogan H.E., Kutlar O.A., Javadzadehkalkhoran M., Demirci A. Investigation of burn duration and NO emission in lean mixture with CNG and gasoline. Energies, vol. 12(23), 2019, pp. 1-18.

[23]Zhang W., Li Z., Jiao P., Shen B., Wang H., Zhang, H. Experimental investigation of emission characteristics based on new alcohol-based gasoline fuel. Advances in Mechanical Engineering, vol. 9(11), 2017, 9 p.

[24] Czerwinski J., Heeb N., Zimmerli Y., Forss A., Hilfiker T., Bach C. Unregulated emissions with TWC, gasoline \& CNG. SAE International Journal of Engines, vol. 3(1), 2010, pp. 1099-1112.

[25] Borawski A. Modification of a fourth generation LPG installation improving the power supply to a spark ignition engine. Eksploatacja i Niezawodnosc - Maintenance and Reliability, vol. 17(1), 2015, pp. 1-6.

[26] WLTP lab test. [online] [10.11.2019]. Available at: http://wltpfacts.eu/.

[27] Szpica D. Investigating fuel dosage non-repeatability of low pressure gas-phase injectors. Flow Measurement and Instrumentation, vol. 59, 2018, pp. 147-156.

[28] Szpica D. Research on the influence of LPG/CNG injector outlet nozzle diameter on uneven fuel dosage. Transport, vol. 33(1), 2018, pp. 186-196.

[29] Mieczkowski G. Stress fields at the tip of a sharp inclusion on the interface of a bimaterial. Mechanics of Composite Materials, vol. 52(5), 2016, pp. 601-610.

[30] Mieczkowski G. Stress fields and fracture prediction for adhesively bonded bi-material structure with sharp notch located on the interface. Mechanics of Composite Materials, vol. 53(3), 2017, pp. 305-320.

[31] Mieczkowski G., Molski K., Seweryn A. Finite-element modeling of stresses and displacements near the tips of pointed inclusions. Materials Science, vol. 43(2), 2007, pp. 183-194.

[32] Mieczkowski G., Borawski A., Szpica D. Static electromechanical characteristic of a three-layer circular piezoelectric transducer, Sensors, vol. 20, 2020, 222, 14 p.

[33] Borawski A. Common methods in analysing the tribological properties of brake pads and discs - a review. Acta Mechanica et Automatica, vol. 13(3), 2019, pp. 189-199.

[34] Borawski A. Suggested research method for testing selected tribological properties of friction components in vehicle braking systems. Acta Mechanica et Automatica, vol. 10(3), 2016, pp. 223 226.

[35] Commission Regulation (EU) 2017/1154 of 7 June 2017 amending Regulation (EU) 2017/1151 supplementing Regulation (EC) No 715/2007 of the European Parliament and of the Council on type-approval of motor vehicles with respect to emissions from light passenger and commercial vehicles (Euro 5 and Euro 6) and on access to vehicle repair and maintenance information, 
amending Directive 2007/46/EC of the European Parliament and of the Council, Commission Regulation (EC) No 692/2008 and Commission Regulation (EU) No 1230/2012 and repealing Regulation (EC) No 692/2008 and Directive 2007/46/EC of the European Parliament and of the Council as regards real-driving emissions from light passenger and commercial vehicles (Euro 6). Official Journal of the European Union, L175, 7.7.2017, 708 p.

[36] Setiyo M., Waluyo B., Anggono W., Husni M. Performance of gasoline/LPG BI-fuel engine of manifold absolute pressure sensor (MAPS) variations feedback. ARPN Journal of Engineering and Applied Science, vol. 11(7), 2016, pp. 4707-4712.

[37] Garbala K., Piekarski W., Andrzejewska S., Witaszek K. Analysis of operating parameters and indicators of a compression ignition engine fuelled with LPG. Scientific Journal of Silesian University of Technology. Series Transport, vol. 93, 2016, pp. 13-22. 